Part of Journal of Research of the National Bureau of Standards, Volume 29, November 1942

\title{
A REEXAMINATION OF THE POTSDAM ABSOLUTE DETERMINATION OF GRAVITY
}

\author{
By Hugh L. Dryden
}

\begin{abstract}
Recent absolute determinations of the acceleration of gravity differ from the generally accepted Potsdam value by amounts considerably greater than the probable error assigned to that value by the Potsdam investigators. The discrepancy is due in large part to an adjustment made with the intent of correcting for certain systematic errors. The adjustment was probably not warranted. If this adjustment is not made, the Potsdam result is about 12 parts per million less than the commonly accepted value as compared with 14 and 20 parts per million less as found in the recent absolute determinations. The best value of $g$ for general use when accurate absolute values are needed is probably obtained by reducing the local value in the Potsdam system by about 15 parts per million. The Subcommittee on Gravity of the National Research Council Committee on Fundamental Physical Constants has recommended a reduction of 17 parts per million.
\end{abstract}

\section{CONTENTS}

II. The Pots

II. The Potsdam pendulums

III. Observed results _.

IV. The final adjustment

V. Suggested revision of Potsdam value

VI. Best value of $g$

\section{INTRODUCTION}

The present accepted international base for gravity measurements is Potsdam, Germany. The value of gravity for the base station, $981.274 \mathrm{~cm} / \mathrm{sec}^{2}$, is the result of an absolute determination by $\mathrm{F}$. Kühnen and Ph. Furıwängler, whose observations are described in great detail in a 1906 publication of the Königliche Preussische Geödatische Institut entitled "Bestimmung der absoluten Grösse der Schwerkraft zu Potsdam mit Reversionspendeln." The completeness of the investigation and of the report, which includes a discussion of all the suggested sources of accidental and systematic error, has won universal acceptance for this value.

However, recent determinations indicate that the Potsdam value is too large. Thus, in 1936, Paul R. Heyl and Guy S. Cook published ${ }^{1}$ the results of an absolute determination at Washington, also made with reversible pendulums, which gave a result $0.020 \mathrm{~cm} / \mathrm{sec}^{2}(20$ parts per million) lower than the value derived from the Potsdam

\footnotetext{
1 J. Research NBS 17, 805 (1936) RP946.
} 
value by means of a direct connection between the two stations made in $1933^{2}$ by E. J. Brown, of the United States Coast and Geodetic Survey.

In $19399^{3} \mathrm{~J}$. S. Clark published the results of an absolute determination at the National Physical Laboratory, Teddington, England, again made with a reversible pendulum, which gave a result $0.013_{8}$ $\mathrm{cm} / \mathrm{sec}^{2}$ (14 parts per million) lower than the value derived from the Potsdam value and a number of transfer measurements adjusted by E. C. Bullard and H. L. P. Jolly. ${ }^{4}$

Relative measurements between Teddington and Washington have recently been made by B. C. Browne and E. C. Bullard. ${ }^{5}$ These relative measurements gave a difference between the acceleration of gravity at Teddington and Washington of $1.096_{9} \mathrm{~cm} / \mathrm{sec}^{2}$, whereas the difference between the absolute measurements was $1.101_{5} \mathrm{~cm} / \mathrm{sec}^{2}$, that is, agreement within 4.6 parts per million. Browne and Bullard conclude that there is "little doubt that the hitherto accepted value at Potsdam is some seventeen parts in a million too great" and that "this correction should be applied to values in the Potsdam system when values of $g$ are to be used in connection with other physica] quantities (for example in the determination of the electrical units.)"

The present paper summarizes the result of a study of the Potsdam determination made at the time that Heyl and Cook's paper was under editorial review. It is now published in view of interest in the selection of the "best" value of $g$ for use in the work of the National Research Council Committee on Fundamental Physical Constants. The reexamination of the Potsdam result shows that the value obtained after correction for known effects was 11.8 parts per million lower than that finally given, the mean value having been changed by this amount as a result of a procedure intended to correct for certain types of systematic errors. There is some doubt as to the effectiveness of this procedure.

There is great need of an absolute determination by some other method than that of the reversible pendulum to determine definitely the magnitude of the systematic errors present in the measurements with reversible pendulums. Under present world conditions, however, other scientific problems are much more urgent, and this one must await more normal times.

\section{THE POTSDAM PENDULUMS}

Five pendulums were used by Kühnen and Furtwängler, each consisting of a tube with a heavy solid cylindrical weight on one end and a light hollow weight of the same external shape and dimensions on the other end. The lengths of the tubes were between 1,116 and $1,125 \mathrm{~mm}$; the external diameters were between 41 and $44 \mathrm{~mm}$; and the wall thicknesses were between 1 and $2 \mathrm{~mm}$. The five pendulums were designated as follows: Light Austrian (mass, $2.86 \mathrm{~kg}$ ); Geodetic Institute (mass, $5.57 \mathrm{~kg}$ ); Italian (mass, $5.87 \mathrm{~kg}$ ); Heavy Austrian (mass, $6.23 \mathrm{~kg}$ ); Half-second (mass. $3.53 \mathrm{~kg}$ ). The first four were seconds pendulums, so that the distance between the two axes of

\footnotetext{
3 U. S. Coast and Geodetic Survey, Spec. Pub. No. 204 (1936).

3 Phil. Trans. Roy. Soc. (London) [A] 238, 65-123 (1939).

4 Monthly Notices Roy. Astron. Soc.. Geophys. Suppl. 3, 443-477 (1936) and 4, 132 (1937).

- Proc. Roy. Soc. (London) [A] 175, 110 (1940).
} 
rotation was about $100 \mathrm{~cm}$; the last was a half-second pendulum with distance between axes of $24.9 \mathrm{~cm}$.

Each pendulum could be swung on one or more pairs of knife edges fastened to the pendulum, the knife edges resting on planes fixed to the support; or it could be swung on planes fastened to the pendulum, the knife edges being fixed to the support. One pair of knife edges could be used for all five pendulums; these are accordingly designated "universal." In addition, each pendulum had a pair of knife edges; these are designated "own." The two Austrian pendulums used the same pair.

In all the pendulums the knife edges could be removed and interchanged in position, and for all except the light Austrian pendulum, the weights could be interchanged.

With knife edges mounted in the pendulum, the supporting planes were either two agate stones mounted in a small bridgelike support on which all five pendulums could be swung or a larger support intended mainly for the three heaviest pendulums. These supports are designated "small bridge" and "large bridge," respectively.

The measurements on the pendulums with knife edges were made in air at atmospheric pressure; those on the pendulums with planes were made in an evacuated cylinder at pressures from 20 to $760 \mathrm{~mm}$ mercury.

\section{OBSERVED RESULTS}

The procedure followed in the observations may be reviewed briefly as follows: A series of observations on a given pendulum with a given method of support usually occupied 4 days. On the first day, the period was measured first with heavy weight below and then with heavy weight above (i. e. with the pendulum rotated about a horizontal axis, or "reversed"). The pendulum was then rotated about a vertical axis, and the period measured first with heavy weight above and then with heavy weight below. On the second day, the distance between the knife edges was measured for each of the four positions, and the distance of the center of gravity from the knife edges determined. The weights or knife edges were then removed from the pendulum and interchanged. On the third day, length measurements and the center-of-gravity determination were made, and on the fourth day, periods for the four positions were measured as on the first day. Frequently the order was changed to give length measurements on the first and fourth days.

From such a normal series of eight times of swing, four values of the length of the simple seconds pendulum were computed, that is, each sequence of swings with heavy weight above and below was treated independently. Corrections were applied to each individual time of swing for amplitude and damping, for temperature, for vertical temperature gradient, for difference in air density between swings in upright and reversed positions, for clock rate, and, when the planes were fixed in the pendulum, for the angle of inclination between the planes. The apparent length of the simple seconds pendulum was then computed for each pair of times of swing. To these values were applied corrections for the motion of the pendulum support, for flexure of the pendulum, for extension of the pendulum under load, and for asymmetry. There resulted 192 values for the length of the simple seconds pendulum, which are given in full in table 1 . The 
magnitude of the corrections, which have been applied to the observed values to obtain the values given in table 1 , is indicated in table 2 .

TABLE 1.-Potsdam values of length of seconds pendulum after correction for known effects but before final adjustment for unknown systematic errors a

\begin{tabular}{|c|c|c|c|c|c|}
\hline Bearing b & Bridge ${ }^{c}$ & $\begin{array}{l}\text { Change be- } \\
\text { tween de- } \\
\text { termina- } \\
\text { tions d }\end{array}$ & $\begin{array}{l}\text { Length of } \\
\text { a seconds } \\
\text { pendulum } \\
\text { from obser- } \\
\text { vations, } \\
\text { corrected } \\
\left(10^{-7} \text { meter }\right)\end{array}$ & $\begin{array}{c}\text { First } \\
\text { average }\end{array}$ & $\begin{array}{l}\text { Second } \\
\text { average }\end{array}$ \\
\hline
\end{tabular}

\begin{tabular}{|c|c|c|c|c|c|}
\hline $\begin{array}{l}O_{1} \\
O_{1}\end{array}$ & $\begin{array}{l}L \\
L \\
L \\
L\end{array}$ & $\begin{array}{l}K \\
R \\
K\end{array}$ & $\begin{array}{r}9943152 \\
1521 \\
3198 \\
1450\end{array}$ & $\begin{array}{r}9942337 \\
2324\end{array}$ & 9942330 \\
\hline $\begin{array}{l}U^{U} \\
U^{U} \\
U \\
U\end{array}{ }^{-}$ & $\begin{array}{l}S \\
S \\
S \\
S \\
S \\
S \\
S \\
S\end{array}$ & $\begin{array}{l}\not K \\
R \\
K \\
A \\
K \\
R \\
K\end{array}$ & $\begin{array}{l}2374 \\
2332 \\
2336 \\
2395 \\
2318 \\
2426 \\
2377 \\
2427\end{array}$ & $\begin{array}{l}2353 \\
2365 \\
2372 \\
2402\end{array}$ & 2373 \\
\hline $\begin{array}{l}P \\
P \\
P \\
P\end{array}$ & 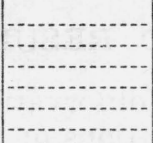 & 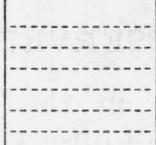 & $\begin{array}{l}2241 \\
2441 \\
2299 \\
2418 \\
2252 \\
2423\end{array}$ & $\begin{array}{l}2341 \\
2358_{5} \\
2337_{5}\end{array}$ & 2346 \\
\hline
\end{tabular}

Geodetic Institute pendulum; mass, $5.57 \mathrm{~kg}$

\begin{tabular}{|c|c|c|c|c|c|}
\hline $\begin{array}{l}O_{1} \\
O_{1}\end{array}$ & $\begin{array}{l}S \\
S \\
S \\
S\end{array}$ & $\begin{array}{l}W \\
R \\
W\end{array}$ & $\begin{array}{r}9942341 \\
2246 \\
2254 \\
2201\end{array}$ & $\begin{array}{r}9942294 \\
2228\end{array}$ & 9942261 \\
\hline $\begin{array}{l}O^{\prime} \\
O^{\prime}\end{array}$ & $\begin{array}{l}S \\
S \\
S \\
S \\
S \\
S \\
S \\
S \\
S\end{array}$ & $\begin{array}{l}D \\
W \\
R \\
W \\
D \\
W \\
R \\
W\end{array}$ & $\begin{array}{l}2267 \\
2255 \\
2242 \\
2281 \\
2282 \\
2193 \\
2361 \\
2223\end{array}$ & $\begin{array}{l}2261 \\
2261 \\
2238 \\
2292\end{array}$ & $\begin{array}{l}2261 \\
2265\end{array}$ \\
\hline $\begin{array}{l}U_{U} \\
U_{U} \\
U^{-}\end{array}$ & $\begin{array}{l}S \\
S \\
S \\
S\end{array}$ & $\begin{array}{l}W \\
R \\
W\end{array}$ & $\begin{array}{l}2379 \\
2093 \\
2377 \\
2209\end{array}$ & $\begin{array}{l}2236 \\
2293\end{array}$ & 2264 \\
\hline$U_{U}^{U} U^{U} U$ & $\begin{array}{l}L \\
L \\
L \\
L\end{array}$ & $\begin{array}{l}W \\
R \\
W\end{array}$ & $\begin{array}{l}2292 \\
2349 \\
2215 \\
2480\end{array}$ & $\begin{array}{l}2320 \\
2348\end{array}$ & 2334 \\
\hline $\begin{array}{l}O^{\prime} \\
O\end{array}$ & $\begin{array}{l}L \\
L \\
L \\
L\end{array}$ & $\begin{array}{l}W \\
R \\
W\end{array}$ & $\begin{array}{l}2123 \\
2391 \\
2111 \\
2373\end{array}$ & $\begin{array}{l}2257 \\
2242\end{array}$ & 2250 \\
\hline$P_{P} P^{P}$ & 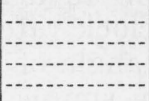 & 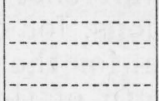 & $\begin{array}{l}2323 \\
2262 \\
2355 \\
2353\end{array}$ & $\begin{array}{l}2292_{5} \\
2354\end{array}$ & 2323 \\
\hline $\begin{array}{l}P \\
P \\
P\end{array}$ & 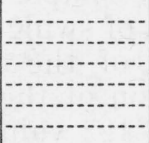 & 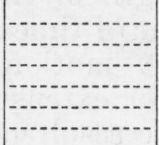 & $\begin{array}{l}2270 \\
2236 \\
2262 \\
2220 \\
2276 \\
2245\end{array}$ & $\begin{array}{l}2253 \\
2241 \\
2260_{5}\end{array}$ & 2252 \\
\hline
\end{tabular}

See footnotes at end of table. 
TABLE 1.-Potsdam values of length of seconds pendulum after correction for known effects but before final adjustment for unknown systematic errors a-Continued

\begin{tabular}{|c|c|c|c|c|c|}
\hline Bearing b & Bridge • & $\begin{array}{l}\text { Change be- } \\
\text { tween de- } \\
\text { termina- } \\
\text { tions d }\end{array}$ & $\begin{array}{l}\text { Length of } \\
\text { a seconds } \\
\text { pendulum } \\
\text { from obser- } \\
\text { vations, } \\
\text { corrected } \\
\left(10^{-7} \text { meter) }\right.\end{array}$ & $\begin{array}{c}\text { First } \\
\text { average }\end{array}$ & $\begin{array}{l}\text { Second } \\
\text { average }\end{array}$ \\
\hline
\end{tabular}

Italian pendulum; mass, $5.87 \mathrm{~kg}$

\begin{tabular}{|c|c|c|c|c|c|}
\hline $\begin{array}{l}O_{0} \\
O_{0}\end{array}$ & $\begin{array}{l}S \\
S \\
S \\
S\end{array}$ & $\begin{array}{l}W \\
R \\
W\end{array}$ & $\begin{array}{r}9942435 \\
2163 \\
2381 \\
2178\end{array}$ & $\begin{array}{r}9942299 \\
2279\end{array}$ & 9942289 \\
\hline$O_{O} O$ & $\underset{S}{S}$ & $\begin{array}{l}K \\
W \\
R \\
W\end{array}$ & $\begin{array}{l}2361 \\
2129 \\
2448 \\
2101\end{array}$ & $\begin{array}{l}2245 \\
2274\end{array}$ & 2259 \\
\hline$O_{O} O_{0}$ & $\begin{array}{l}S \\
S \\
S \\
S\end{array}$ & $\begin{array}{l}K \\
W \\
R \\
W\end{array}$ & $\begin{array}{l}2432 \\
2102 \\
2458 \\
2143\end{array}$ & $\begin{array}{l}2267 \\
2300\end{array}$ & 2283 \\
\hline $\mathrm{O}^{\mathrm{O}}$ & $\begin{array}{l}S \\
S \\
S \\
S\end{array}$ & $\begin{array}{l}K \\
W \\
R \\
W\end{array}$ & $\begin{array}{l}2425 \\
2112 \\
2405 \\
2059\end{array}$ & $\begin{array}{l}2268 \\
2232\end{array}$ & 2250 \\
\hline$O_{0}$ & $\begin{array}{l}S \\
S \\
S \\
S\end{array}$ & $\begin{array}{l}K \\
W \\
R \\
W\end{array}$ & $\begin{array}{l}2405 \\
2062 \\
2372 \\
2072\end{array}$ & $\begin{array}{l}2234 \\
2222\end{array}$ & 2228 \\
\hline$O_{0} O^{\prime}$ & $\begin{array}{l}S \\
S \\
S \\
S\end{array}$ & $\begin{array}{l}K \\
W \\
R \\
W\end{array}$ & $\begin{array}{l}2374 \\
2042 \\
2437 \\
2032\end{array}$ & $\begin{array}{l}2208 \\
2234\end{array}$ & 2221 \\
\hline $\begin{array}{l}O_{0} \\
O\end{array}$ & $\begin{array}{l}S \\
S \\
S \\
S\end{array}$ & $\begin{array}{l}K \\
W \\
R \\
W\end{array}$ & $\begin{array}{l}2238 \\
2102 \\
2224 \\
2059\end{array}$ & $\begin{array}{l}2170 \\
2142\end{array}$ & 2156 \\
\hline$O_{0}$ & $\begin{array}{l}S \\
S \\
S \\
S\end{array}$ & $\begin{array}{l}K \\
W \\
R \\
W\end{array}$ & $\begin{array}{l}2402 \\
2035 \\
2469 \\
2066\end{array}$ & $\begin{array}{l}2218 \\
2267\end{array}$ & 2242 \\
\hline 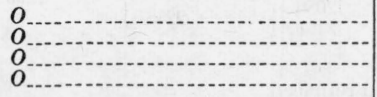 & $\begin{array}{l}L \\
L \\
L \\
L\end{array}$ & $\begin{array}{l}W \\
R \\
W\end{array}$ & $\begin{array}{l}2184 \\
2446 \\
2122 \\
2466\end{array}$ & $\begin{array}{l}2315 \\
2294\end{array}$ & 2304 \\
\hline $\begin{array}{l}U_{U} \\
U_{U} \\
U\end{array}$ & $\begin{array}{l}S \\
S \\
S \\
S\end{array}$ & $\begin{array}{l}W \\
R \\
W\end{array}$ & $\begin{array}{l}2029 \\
2360 \\
2112 \\
2387\end{array}$ & $\begin{array}{l}2194 \\
2249\end{array}$ & 2222 \\
\hline $\begin{array}{l}P \\
P \\
P\end{array}$ & 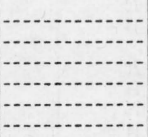 & 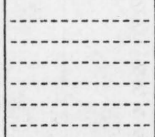 & $\begin{array}{l}2171 \\
2212 \\
2203 \\
2258 \\
2178 \\
2274\end{array}$ & $\begin{array}{l}2191_{s} \\
2230_{s} \\
2226\end{array}$ & 2216 \\
\hline $\begin{array}{l}P \\
P\end{array}$ & -1-n & (-n- & $\begin{array}{l}2210 \\
2293 \\
2188 \\
2306\end{array}$ & $\begin{array}{l}2251_{5} \\
2247\end{array}$ & 2249 \\
\hline $\begin{array}{l}P \\
P \\
P\end{array}$ & & 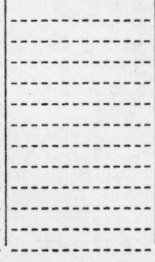 & $\begin{array}{l}1969 \\
1979 \\
2408 \\
1954 \\
1978 \\
2416 \\
2001 \\
1959 \\
2414 \\
1975 \\
1983 \\
2380\end{array}$ & $\begin{array}{l}2191 \\
2191 \\
2197 \\
2179\end{array}$ & 2190 \\
\hline
\end{tabular}

See footnotes at end of table. 
TABLE 1.-Potsdam values of length of seconds pendulum after correction for known effects but before final adjustment for unknown systematic errors a-Continued

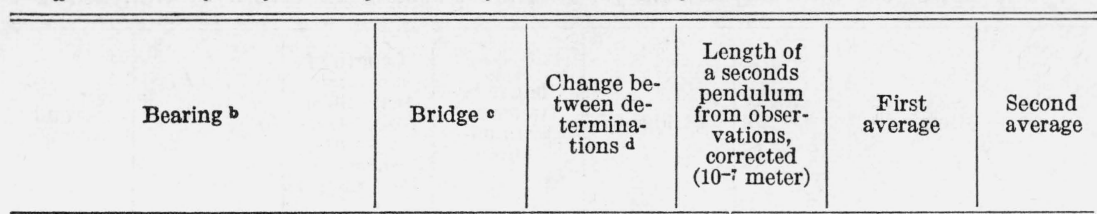

Italian pendulum; mass, $5.87 \mathrm{~kg} .-$ Continued

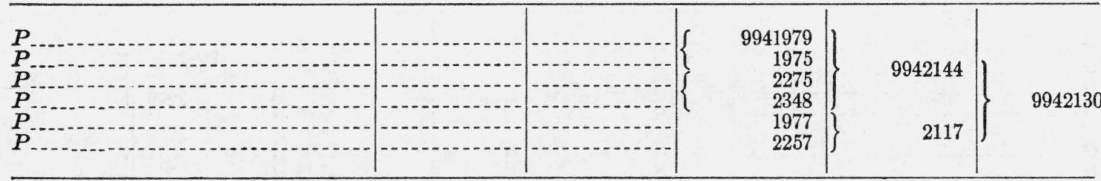

Heavy Austrian pendulum; mass, $6.23 \mathrm{~kg}$

\begin{tabular}{|c|c|c|c|c|c|}
\hline$O_{0} O^{O}$ & $\begin{array}{l}L \\
L \\
L \\
L\end{array}$ & $\begin{array}{l}W \\
R \\
W\end{array}$ & $\begin{array}{r}9941701 \\
2983 \\
1752 \\
2963\end{array}$ & $\begin{array}{r}9942342 \\
2358\end{array}$ & 9942350 \\
\hline$U_{U}^{U} U_{U}$ & $\begin{array}{l}S \\
S \\
S \\
S\end{array}$ & $\begin{array}{l}W \\
R \\
W\end{array}$ & $\begin{array}{l}2152 \\
2226 \\
2177 \\
2305\end{array}$ & $\begin{array}{l}2189 \\
2241\end{array}$ & 2215 \\
\hline $\begin{array}{l}P \\
P \\
P\end{array}$ & (2- & 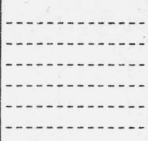 & $\begin{array}{l}2198 \\
2258 \\
2206 \\
2282 \\
2196 \\
2253\end{array}$ & $\begin{array}{l}2228 \\
2244 \\
22245\end{array}$ & 2232 \\
\hline
\end{tabular}

Half-second pendulum; mass, $3.53 \mathrm{~kg}$

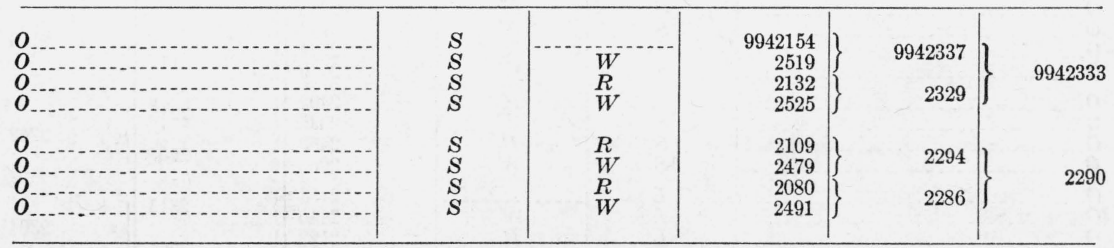

Half-second pendulum - weights removed and replaced

\begin{tabular}{|c|c|c|c|c|c|}
\hline $\begin{array}{l}O_{0} \\
O_{0}\end{array}$ & $\begin{array}{l}S \\
S \\
S \\
S\end{array}$ & $\begin{array}{l}W \\
R \\
W\end{array}$ & $\begin{array}{r}9942575 \\
2180 \\
2557 \\
2122\end{array}$ & $\begin{array}{r}9942378 \\
2339\end{array}$ & 9942358 \\
\hline $\begin{array}{l}O_{1} \\
O_{0}\end{array}$ & $\begin{array}{l}S \\
S \\
S \\
S\end{array}$ & $\begin{array}{l}R \\
W \\
R \\
W\end{array}$ & $\begin{array}{l}2458 \\
2160 \\
2500 \\
2172\end{array}$ & $\begin{array}{l}2309 \\
2336\end{array}$ & 2322 \\
\hline $\begin{array}{l}U^{U} \\
U^{U} \\
U^{\prime} \\
U\end{array}{ }^{-}$ & $\begin{array}{l}S \\
S \\
S \\
S \\
S \\
S \\
S \\
S\end{array}$ & $\begin{array}{l}R \\
A \\
R \\
W \\
R \\
A \\
R\end{array}$ & $\begin{array}{l}2274 \\
2223 \\
2329 \\
2168 \\
2349 \\
2227 \\
2397 \\
2128\end{array}$ & $\begin{array}{l}2249 \\
2249 \\
2288 \\
2262\end{array}$ & 2262 \\
\hline $\begin{array}{l}P \\
P \\
P\end{array}$ & 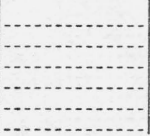 & 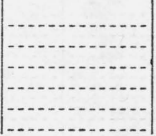 & $\begin{array}{l}1960 \\
2040 \\
1978 \\
2151 \\
1956 \\
2029\end{array}$ & $\begin{array}{l}2000 \\
2014_{8} \\
1992_{5}\end{array}$ & 2002 \\
\hline
\end{tabular}

See footnotes at end of table. 
TABLE 1.-Potsdam values of length of seconds pendulum after correction for known effects but before final adjustment for unknown systematic errors * Continued

\begin{tabular}{c|c|c|c|c|}
\hline \hline Bearing b & Bridge & $\begin{array}{c}\text { Length of } \\
\text { Change be- } \\
\text { tween de- } \\
\text { termina- } \\
\text { tions d } \\
\text { a seconds } \\
\text { pendulum } \\
\text { from obser- } \\
\text { vations, } \\
\text { corrected } \\
\left(10^{-7} \text {.meter }\right)\end{array}$
\end{tabular}$\quad \begin{gathered}\text { First } \\
\text { average }\end{gathered} \mid \begin{gathered}\text { Second } \\
\text { average }\end{gathered}$

Half-second pendulum-weights removed and replaced-Continued

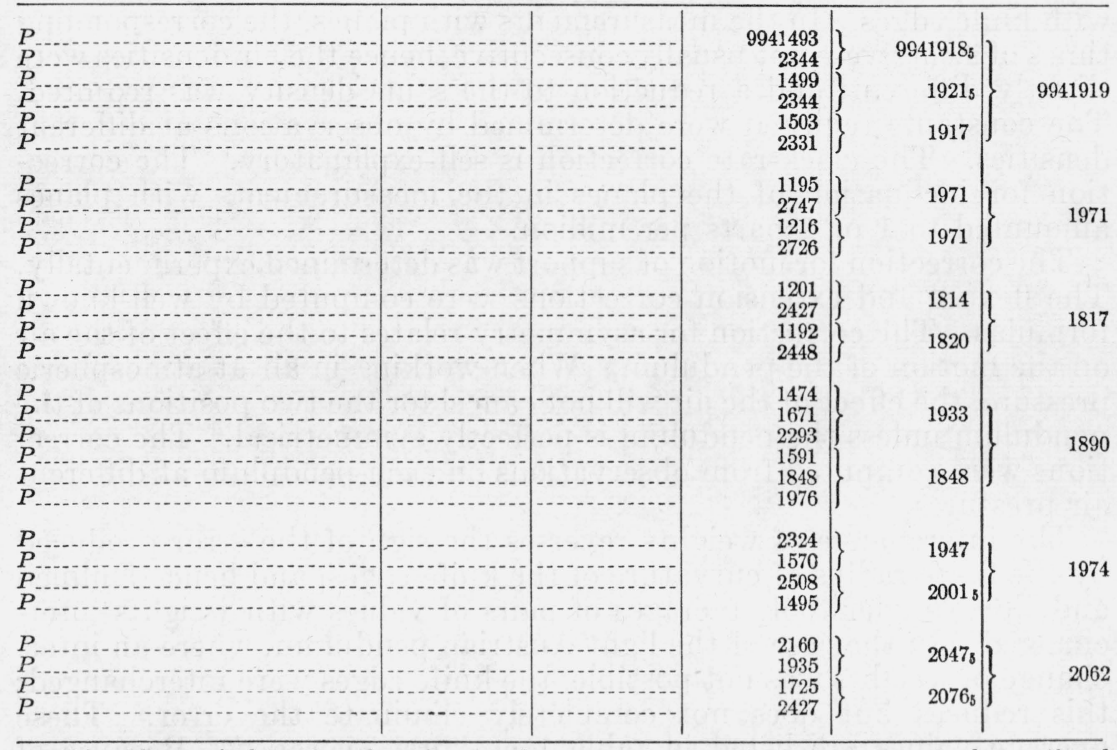

a This table recapitulates the values given in columns 18 and 19 of table 9 , p. 216-233, and columns 19 and 20 of table 13, p. 303-315, of Kühnen and Furtwängler's report, rearranged to bring together the values for a given pendulum.

b $O=0$ wn knife edges, $U=$ universal knife edges, $P=$ planes.

- $L=$ large bridge, $S=$ small bridge.

d This column gives change made since preceding run.

$R=$ pendulum rotated about vertical axis.

$K=$ knife edges interchanged.

$W=$ weights interchanged.

$A=$ change in amplitude.

$D=$ change in azimuth of plane of vibration.

TABLE 2.-Magnitude of corrections applied by Kühnen and Furtwängler for known effects

\begin{tabular}{|c|c|c|c|c|c|}
\hline \multicolumn{4}{|c|}{ Source of correction } & \multicolumn{2}{|c|}{$\begin{array}{l}\text { Magnitude (parts in } \\
\left.10^{7}\right)\end{array}$} \\
\hline \multicolumn{4}{|c|}{$\begin{array}{l}\text { Amplitude and damping } \\
\text { Temperature } \\
\text { Vertical temperature gradient } \\
\text { Air density } \\
\text { Clock rate } \\
\text { Angle of inclination of planes. }\end{array}$} & \multicolumn{2}{|c|}{$\begin{array}{l}-30 \text { to }-1 \\
-196 \text { to }+129 \\
-2 \text { to }+1 \\
-182 \text { to }+385 \\
-615 \text { to }+40 \\
-11 \text { to }+21\end{array}$} \\
\hline & $\begin{array}{l}\text { Light } \\
\text { Austrian }\end{array}$ & $\begin{array}{l}\text { Geodetic } \\
\text { Institute }\end{array}$ & Italian & $\underset{\text { Austrian }}{\text { Heavy }}$ & $\begin{array}{l}\text { Half- } \\
\text { second }\end{array}$ \\
\hline $\begin{array}{l}\text { Motion of support } \\
\text { Flexure } \\
\text { Extension under load } \\
\text { Asymmetry, heavy weight below } \\
\text { Asymmetry, heavy weight above }\end{array}$ & $\begin{array}{r}14 \\
-48 \\
11 \\
32 \\
32\end{array}$ & $\begin{array}{r}27 \\
-37 \\
15 \\
9 \\
-48\end{array}$ & $\begin{array}{r}28 \\
-47 \\
11 \\
-118 \\
-91\end{array}$ & $\begin{array}{r}30 \\
-41 \\
13 \\
-13 \\
10\end{array}$ & $\begin{array}{r}69 \\
20 \\
7 \\
-64 \\
40\end{array}$ \\
\hline
\end{tabular}


No attempt will be made to discuss the details of these corrections. Amplitude and damping corrections are by well-known formulas; they amount at most to 3 parts per million. The temperature correction relates to the thermal expansion of the pendulum; the values depend on the reference temperature selected and for the majority of the observations were only a few parts per million, much less than the maximum values given in table 2 . The correction for vertical temperature gradient did not exceed 2 parts in 10 million. Except in a few series no air-density correction was required in the measurements with knife edges. In the measurements with planes, the corresponding times of swing were not usually consecutive; hence the air densities were slightly different, and a reduction to the same density was required. The constants required were determined by observations at different densities. The clock-rate correction is self-explanatory. The correction for inclination of the planes in the measurements with planes amounted to 1 or 2 parts per million.

The correction for motion of support was determined experimentally. The flexure and extension corrections were computed by well-known formulas. The correction for asymmetry relates to the effect of the air on the motion of the pendulum. When working in air at atmospheric pressure, the effect of the air will not cancel for the two positions of the pendulum unless the pendulum is perfectly symmetrical. The corrections were computed from observations on each pendulum at different air pressures.

The interchange of weights reverses the sign of the error produced by the finite radius of curvature of the knife edges, and hence Kühnen and Furtwängler took averages of pairs of values with weights interchanged. In the case of the light Austrian pendulum, where an interchange of weights was not possible, the knife edges were interchanged; this reduces but does not completely eliminate the error. These average values are listed in table 1 as "first average." Because of rearrangement of the observations, table 1 indicates a greater number of weight and knife-edge interchanges than were actually made. As previously stated, observations with the pendulum rotated about a vertical axis were usually made before the interchange of weights.

Those observations made in the same series of (usually) 4 days were then averaged to give 40 values, which are designated "second average" in table 1. These values Kühnen and Furtwängler consider of equal weight. They range from 9941817 to $9942373 \times 10^{-7} \mathrm{~m}$, the maximum difference being 56 parts per million. These 40 values were next subjected to a least-squares adjustment described in the next section, which gave an adjusted value of $9942380 \times 10^{-7} \mathrm{~m}$, higher than any one of the 40 values.

Before discussing this adjustment, it is of interest to consider the relation between various weighted mean values of the data given in table 1 to the adjusted value. Various mean values are given in table 3 , together with the average deviation of the individual observations from the mean.

The mean values for each pendulum with knife edges and with planes agree within 5 parts per million except for the half-second pendulum, for which the values differ by 35 parts per million. The average deviation of any single observation from the mean for a given pendulum and support varies from 1 to 7 parts per million. Various 
methods of weighting give mean values which are from 12 to 17 parts per million lower than the final adjusted value.

TABLE 3.-Comparison of arious mean values with final adjusted value given by Kühnen and Furtwängler

\begin{tabular}{|c|c|c|c|c|c|}
\hline Pendulum & Support & $\begin{array}{l}\text { Mean } \\
\text { value }\end{array}$ & $\begin{array}{c}\text { Number of } \\
\text { observa- } \\
\text { tions }\end{array}$ & $\begin{array}{c}\text { Average } \\
\text { deviation } \\
\text { from mean }\end{array}$ & $\begin{array}{l}\text { Amount } \\
\text { below final } \\
\text { adjusted } \\
\text { value a }\end{array}$ \\
\hline Light Austrian, & Knife edges....... & 9942359 & 6 & 21 & 21 \\
\hline Digne Austian, A... & Slanes & $\begin{array}{l}2346 \\
2273\end{array}$ & $\begin{array}{r}3 \\
12\end{array}$ & $\begin{array}{r}9 \\
31\end{array}$ & \\
\hline Geodetic Institute, $B$. & $\left\{\begin{array}{l}\text { Rnanes } \\
\text { Planes. }\end{array}\right.$ & $\begin{array}{l}2273 \\
2280\end{array}$ & $\begin{array}{r}12 \\
5\end{array}$ & $\begin{array}{l}31 \\
34\end{array}$ & $\begin{array}{l}107 \\
100\end{array}$ \\
\hline Italian, $C_{-}$ & $\left\{\begin{array}{l}\text { Knife edges....... } \\
\text { Planes }\end{array}\right.$ & $\begin{array}{l}2246 \\
2197\end{array}$ & 20 & 35 & 134 \\
\hline Heavy Austrian & Knife edges. & 2283 & $\begin{array}{r}11 \\
4\end{array}$ & $\begin{array}{l}31 \\
68\end{array}$ & $\begin{array}{r}183 \\
97\end{array}$ \\
\hline Heavy Austrian & Planes & 2232 & 3 & 8 & 148 \\
\hline Half-second, $E$ & 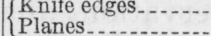 & $\begin{array}{l}2305 \\
1950\end{array}$ & $\begin{array}{l}12 \\
16\end{array}$ & $\begin{array}{l}33 \\
60\end{array}$ & $\begin{array}{r}75 \\
430\end{array}$ \\
\hline \multirow{5}{*}{\multicolumn{2}{|c|}{$\begin{array}{l}\text { BCD } \\
\text { A BCD } \\
\text { All, } 92 \text { first averages of table } 1 \text { given equal weight } \\
\text { All, mean values for each pendulum given equal weight } \\
\text { All, values for } 18 \text { pendulum and support combinations } \\
\text { given equal weight. }\end{array}$}} & 2247 & 55 & 39 & 133 \\
\hline & & 2262 & 64 & 49 & 118 \\
\hline & & 2213 & 92 & 102 & 167 \\
\hline & & 2244 & (5) & 63 & 136 \\
\hline & & 2263 & (18) & 60 & 117 \\
\hline \multicolumn{2}{|c|}{$\begin{array}{l}\text { All, values of } 40 \text { second averages of table } 1 \text { given equal } \\
\text { weight. }\end{array}$} & 2212 & $(40)$ & 98 & 168 \\
\hline
\end{tabular}

a The final adjusted value is 9942380 , to which a correction of +10 is applied for the effect on the length measurements of the rising temperature produced by the presence of the observers. The result is given as $L=994.239 \pm 0.003$, from which $g=981.274 \pm 0.003 \mathrm{~cm} / \mathrm{sec}^{2}$ at Potsdam.

\section{THE FINAL ADJUSTMENT}

The final adjustment was intended to correct for systematic errors arising from the deformation of the knife edges and planes and other departures from the assumed conditions of infinitely small frictionless swinging of the pendulum about a fixed axis of rotation.

The first source of error discussed is that arising from the finite radius of curvature of the knife edge, the contact being assumed to be a rolling contact between a cylinder and plane or between two cylinders. Systematic errors from this source are eliminated by interchanging the weights or knife edges when the knife edges are mounted in the pendulum and are negligible when planes are mounted in the pendulum.

The second type of contact discussed is that in which the knife edge of finite radius makes a cylindrical depression in the supporting plane and slips as the pendulum swings, as if rotating in a cylindrical bearing. The error from this source is shown to be inversely proportional to the distance between the knife edges.

The third type of contact is the same as the preceding except that under the lateral load arising from the reaction at the support, the knife edge is assumed to bend elastically and the contact area of the plane is also assumed to deform laterally. The effect is in general the same as that of motion of the pendulum support, except that it can not be detected by the usual method of measuring the motion of the support. The error from this source consists of two terms, one inversely proportional to the distance between knife edges, the second directly proportional to the mass and inversely proportional to the distance between knife edges.

Systematic errors of this form are undoubtedly present. Kühnen and Furtwängler assume that their observations are sufficiently numerous 
and accurate to determine the magnitude of these errors from the observations on the different pendulums which vary in mass and distance between knife edges. Tacitly it is also assumed that systematic errors which do not vary with the mass and distance between knife edges have the characteristics of accidental errors.

The following steps are straightforward. It is assumed that the adjusted value $L$ is given by the formula

$$
L=L^{\prime}+\frac{q}{\Lambda}+\frac{M}{\Lambda} p,
$$

in which $L^{\prime}$ is the value corrected for known effects (the second average values in table 1 ), $\Lambda$ is the distance between knife edges, $M$ the mass, and $p$ and $q$ are unknown coefficients to be determined from the observations. Forty observation equations are set up, normal equations formed and solved. Any reasonable combination of results gives a correction of 10 to 17 parts per million to be added to the mean value. The results give a practically constant value of $p$ for all conditions of support of 30 , a value of $q$ for knife edges in the pendulum of -82 , and a value of $q$ for planes in the pendulum of $-9, L$ being in units of $10^{-7}$ meter. The effect of the adjustment is shown in table 4 .

TABLE 4.-Effect of final adjustment on values for individual pendulums

\begin{tabular}{|c|c|c|c|c|c|c|c|}
\hline Pendulum & Support & $\begin{array}{c}\text { Mean } \\
\text { value } \\
\text { before } \\
\text { adjust- } \\
\text { ment }\end{array}$ & $\begin{array}{c}\text { Deviation } \\
\text { from mean } \\
\text { of all be- } \\
\text { fore adjust- } \\
\text { ment }\end{array}$ & $\begin{array}{c}p \\
\text { correc- } \\
\text { tion }\end{array}$ & $\begin{array}{c}q \\
\text { correc- } \\
\text { tion }\end{array}$ & $\begin{array}{l}\text { Mean } \\
\text { value } \\
\text { after } \\
\text { adjust- } \\
\text { ment }\end{array}$ & $\begin{array}{l}\text { Deviation } \\
\text { from mean } \\
\text { of all after } \\
\text { adjust-- } \\
\text { ment }\end{array}$ \\
\hline Light Austrian & Knife edges & 9942359 & 112 & 86 & -82 & 9942363 & -19 \\
\hline Geodetic & $\begin{array}{l}\text { Planes } \\
\text { Knnife edges. }\end{array}$ & $\begin{array}{l}2346 \\
2273\end{array}$ & $\begin{array}{l}99 \\
26\end{array}$ & $\begin{array}{r}86 \\
167\end{array}$ & $\begin{array}{r}-9 \\
-82\end{array}$ & $\begin{array}{l}2423 \\
2358\end{array}$ & $\begin{array}{r}41 \\
-24\end{array}$ \\
\hline & Planes & 2280 & 33 & 167 & -9 & 2438 & 5 \\
\hline Italian. & Knife edges & 2246 & -1 & 176 & -82 & 2340 & -42 \\
\hline Heavy Austri & $\begin{array}{l}\text { Planes } \\
\text { KKnife edges.. }\end{array}$ & $\begin{array}{l}2197 \\
2283\end{array}$ & $\begin{array}{r}-50 \\
36\end{array}$ & $\begin{array}{l}176 \\
187\end{array}$ & $\begin{array}{r}-9 \\
-82\end{array}$ & $\begin{array}{l}2364 \\
2338\end{array}$ & \\
\hline \multirow{3}{*}{ Half-second.. } & Planes & 2232 & $\begin{array}{l}-15 \\
-15\end{array}$ & 187 & $\begin{array}{r}-9 \\
-308\end{array}$ & 2410 & 28 \\
\hline & $\left\{\begin{array}{l}\text { Knife edges } \\
\text { Planes_. }\end{array}\right.$ & $\begin{array}{l}2305 \\
1950\end{array}$ & $\begin{array}{r}58 \\
-97\end{array}$ & $\begin{array}{l}424 \\
424\end{array}$ & $\begin{array}{r}-328 \\
-36\end{array}$ & $\begin{array}{l}2401 \\
2338\end{array}$ & $\begin{array}{r}19 \\
-44\end{array}$ \\
\hline & A verage & \& 2247 & 53 & & & a 2382 & 31 \\
\hline
\end{tabular}

a These values differ from those in table 3 and from Kühen and Furtwängler's adjusted mean value by 2 or 3 parts in $10^{-7}$, because here each pendulum is given equal weight, whereas, in ithe other places each determination is given the same weight. 6

\section{thate}

the assumptions underlying the adjustment are granted, no fault can be found with the details of the adjustment. Kühnen and Furtwängler point out the very uneven contribution of the various pendulums to the final values. Thus observations on the half-second pendulum do not enter at all into the determination of $p$, although the largest $p$ correction is applied to that pendulum. The final value of $L$ is determined largely by the results on the light Austrian pendulum (9 out of 92 observations). The final result is equivalent to taking the weighted mean for the results of all the pendulums when the following weights have been assigned: Light Austrian, 1.00; half-second, 0.33; Geodetic Institute, 0.20; Italian, 0.11; heavy Austrian, 0.003 . 
The $p$ term arises from the lateral motion of the axis of rotation produced by bending of the knife edge and the lateral distortion of the contact area of the plane. It is of the same nature as the lateral motion of the pendulum support for which the correction was determined experimentally. The least-squares adjustment gives a $p$ correction six times that made for motion of the pendulum support, which would mean lateral motions due to the deformation six times as great as those of the support as a whole.

W. R. Osgood, of this Bureau, has computed the bending of the knife edge on the basis of the theory of elasticity and concludes that it is highly improbable that the effect of bending of the knife edge could amount to as much as 1 part in a million in the value of the length of the seconds pendulum.

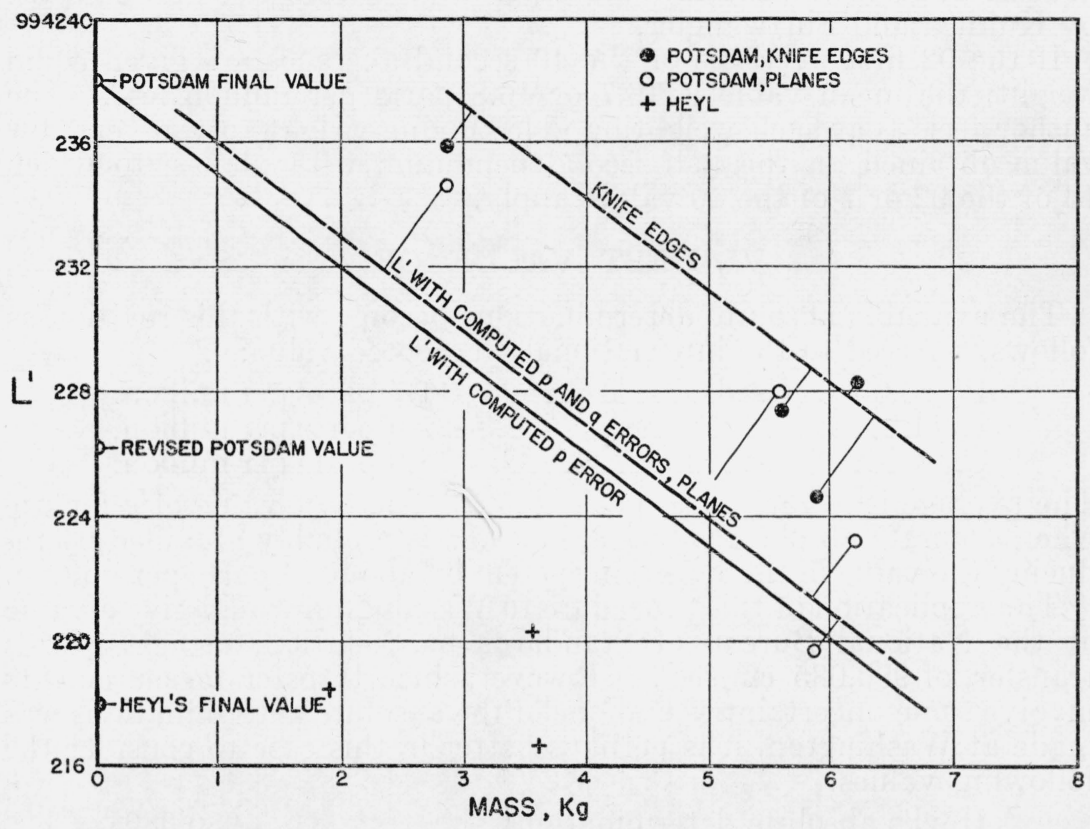

Figure 1.-Potsdam final adjustment interpreted as extrapolation to zero mass.

As stated previously, the observations with the half-second pendulum have no influence on the computation of the $p$ correction. We may then regard the $p$ correction as amounting to an extrapolation of the observed values on pendulums of the same length, which appear to vary with the mass, to a pendulum of zero mass. Figure 1 shows the mean values listed in table 4 plotted against the mass, and the $p$ correction. In this figure are also plotted Heyl's values, which do not indicate a systematic variation with mass, though admittedly the same range of pendulum weight was not studied.

In the light of the more recent determinations and the preceding discussion, doubt is cast on the validity of the adjustment. Kühnen and Furtwängler in their discussion of the adjustment suggest that "if different reversible pendulums are to serve in the most favorable way for a determination of gravity, one must determine in advance of 
the manufacture of the pendulums the masses and knife edge distances according to formula 131." This suggestion was not adopted by the later workers.

\section{SUGGESTED REVISION OF POTSDAM VALUE}

It is suggested that the systematic errors present in the individual Potsdam determinations arose from other causes than those discussed and that in the absence of further knowledge they should be considered of a random nature. From the good consistency of observations in any given pendulum-support combination, it is probable that the systematic errors depend on these combinations alone, being reasonably constant for any given combination. The mean values for each of the 18 combinations should then be given equal weight, which, as indicated in table 3 , gives a value 11.7 parts per million less than that adopted by Kühnen and Furtwängler.

If the 92 first averages or the 40 second averages are given equal weight, the mean value is 16.7 or 16.8 parts per million less. The author feels that such weighting gives undue weight to the very low value obtained on the half-second pendulum with planes, to which 16 of the 92 or 7 of the 40 values apply.

\section{BEST VALUE OF $g$}

The available absolute determinations become with this revision as follows, referred to the internationally accepted value:

Potsdam (revised) . . . . . . . -11.7 parts per million.

Heyl _...

Clark - .

The average is -15.2 parts per million. The best value of $g$ for use when accurate absolute values are needed is probably obtained by reducing the value in the Potsdam system by about 15 parts per million.

The application of this procedure to Washington would give a value at the National Bureau of Standards base station, using Brown's transfer, of $980.085 \mathrm{~cm} / \mathrm{sec}^{2}$. However, since transfer measurements involve some uncertainties and one of the absolute determinations was made at Washington, it is perhaps better in this case to consider the following values:

Heyl's absolute determination

Clark's determination with Browne and Bullard's transfer . . . .

Potsdam determination (revised) with Brown's transfer . . .

Giving the absolute determination made on the spot twice the weight of the other two, a value of 980.083 is obtained. This is believed to be a somewhat better value for use in connection with the absolute electrical measurements made at the National Bureau of Standards.

The Subcommittee on Gravity of the National Research Council Committee on Fundamental Physical Constants by somewhat different reasoning has recommended a reduction of values in the Potsdam system by 17 parts per million, corresponding to 980.083 at Heyl's station, in those cases where the most precise absolute values are desired.

Washington, October 29, 1941. 